\title{
Immunitet personalny najwyższych funkcjonariuszy państwa - problemy najnowszej praktyki
}

\section{Wprowadzenie}

Kategoria najwyższych funkcjonariuszy ${ }^{1}$ państwa posiada szczególne znaczenie z punktu widzenia immunitetów mających swoje źródło w prawie międzynarodowym. Gros orzecznictwa i kierunki ewolucji prawa immunitetów związane były ze sprawami dotyczącymi ich ochrony przed obcą jurysdykcją. W tej dziedzinie najbardziej dobitnie znajduje odzwierciedlenie jeden z podstawowych dylematów współczesnego prawa międzynarodowego, czyli - idąc za słowami sędziów MTS - pogodzenie stabilności w stosunkach międzynarodowych z zasadą odpowiedzialności za najpoważniejsze zbrodnie².

Ustalenie norm prawa międzynarodowego w tym obszarze stało się tym bardziej istotne, że w ostatnich latach chodziło w znacznej mierze o rozstrzygnięcie spraw dotyczących funkcjonariuszy ciągle pełniących swoje funkcje, a zatem

${ }^{1}$ W niniejszej analizie posługujemy się pojęciem „najwyższy funkcjonariusz państwa” (ang. high official), choć termin ten nie jest używany jednolicie. W zależności od źródła, mowa jest także o „urzędniku”, „organie”, ,agencie” lub „przedstawicielu”. Uznajemy, że ten ostatni termin właściwszy jest dla określenia reprezentanta państwa w stosunkach międzynarodowych, w szczególności w prawie dyplomatycznym. Tymczasem pojęcie „funkcjonariusz” ma w omawianym tle znaczenie ogólniejsze i może obejmować ochronę przez immunitet we wszystkich sytuacjach, w których korzysta on ze swoich prerogatyw i nie dotyczy tylko działań podejmowanych w kontekście międzynarodowym. Por. R. Kolodkin, Preliminary report on immunity of State officials from foreign criminal jurisdiction, Doc. UN A/CN.4/601.

2 Wspólna opinia sędziów Higgins, Kooijmansa i Buerghentala, sprawa nakazu aresztowania z 11 kwietnia 2000 r., ICJ Rep. 2002, pkt 5. 
określenia zakresu przysługującego im immunitetu personalnego (ratione personae). Przypomnijmy, że jego celem jest zapewnienie ochrony określonej, wąskiej kategorii najwyższych funkcjonariuszy. Immunitet ten obejmuje zarówno czyny popełnione przy wykonywaniu obowiązków służbowych (official acts), jak i niemające takiego charakteru (private acts), popełnione zarówno w okresie, kiedy osoba ta pełniła funkcję państwową, jak i przed objęciem tej funkcji. Innymi słowy, zapewnia on całkowitą nietykalność (ma charakter absolutny). Immunitet personalny wygasa $\mathrm{z}$ chwilą zakończenia sprawowania funkcji. Różni się on zatem zasadniczo od immunitetu materialnego (ratione materiae), który chroni wszystkich funkcjonariuszy państwowych (ma zatem szerszy zakres podmiotowy), jednakże obejmuje wyłącznie działania podejmowane w ramach obowiązków służbowych. W przeciwieństwie do immunitetu personalnego, nie jest ograniczony temporalnie, a tym samym ochrona nie ustaje po zakończeniu sprawowania urzędu. Rzecz jasna, immunitet personalny i materialny ze sobą współistnieją i w pewnym zakresie mogą się nakładać3.

Uzasadnienie istnienia immunitetu personalnego wywodzi się przede wszystkim z przesłanek funkcjonalnych. W związku z pełnionymi funkcjami, osoby objęte tym immunitetem muszą stale reprezentować państwo w stosunkach międzynarodowych. Narażenie na ingerencję ze strony obcego wymiaru sprawiedliwości mogłoby podważać niezakłócone pełnienie tych funkcji (ne impediatur legatio) ${ }^{4}$. Tradycyjnie wskazuje się też na co najmniej dwa inne motywy stojące za instytucją immunitetu personalnego - związane z zasadą symbolicznej suwerenności (głowa państwa i inni najwyżsi funkcjonariusze uosabiają państwo), a także zasadą nieingerencji w sprawy drugiego państwa (par in parem non habet imperium) 5 .

Praktyka orzecznicza w omawianym zakresie była przez długi czas dość uboga. Orzecznictwo po II wojnie światowej, zarówno rozwijane przez trybunały międzynarodowe, jak i sądy krajowe, dotyczyło obalonych funkcjonariuszy państwa (a tym samym immunitetu materialnego, nie zaś personalnego). Również znacznie późniejsza praktyka, jak choćby sprawa Pinocheta prowadzona przed organami hiszpańskimi ${ }^{6}$ i brytyjskimi ${ }^{7}$, nie mogła przynieść bezpośrednich wytycznych co do stanu prawa międzynarodowego w zakresie immunitetu personalnego najwyższych funkcjonariuszy państwa, gdyż generał nie pełnił już wówczas funkcji państwowych.

${ }^{3}$ Por. A. Cassese, International Criminal Law, Oxford 2008, s. 304.

${ }^{4}$ Por. Sprawa nakazu aresztowania, pkt 53.

5 Por. M. Shaw, Prawo międzynarodowe, Warszawa 2000, s. 375; I. Brownlie, Principles of Public International Law, Oxford 2003, s. 573; P. Daillier, A. Pellet, Droit international public, Paris 2002, s. 450; D. Akande, S. Shah, Immunities of State Officials, International Crimes, and Foreign Domestic Courts, EJIL 2010, vol. 21, s. 824.

${ }^{6}$ Zob. M. Del Carmen Marquez Carrasco, J. Alcaide Fernandez, In re Pinochet, AJIL 1999, nr 3, s. 690.

7 Zob. D. Woodhouse (red.), The Pinochet Case. A Legal and Constitutional Analysis, Oxford 2000 . 
Ponadto, czynnikiem komplikującym ustalenie obowiązujących norm jest charakter źródeł formalnych immunitetu personalnego. Jak wskazał MTS, istniejące konwencje regulują zakres immunitetu dyplomatycznego i o ile mogą dostarczać „użytecznych wskazówek” (provide useful guidance), to nie dotyczą ochrony, z której korzystają ministrowie spraw zagranicznych (ani inni najwyżsi funkcjonariusze obcego państwa) ${ }^{8}$. W związku z tym rozstrzygnięcia w tej dziedzinie muszą odbywać się w oparciu o prawo zwyczajowe, które ze swojej istoty jest trudniejsze do precyzyjnego ustalenia.

Niniejszy tekst stanowi analizę najnowszej praktyki w zakresie ochrony najwyższych funkcjonariuszy państw przez immunitet personalny. Problem ten należy rozpoznać na dwóch płaszczyznach instytucjonalnych: forum obcego państwa oraz trybunału międzynarodowego. Za najnowszą praktykę uznana jest ta mająca miejsce po kluczowym na tle omawianej problematyki wyroku MTS z 14 lutego 2002 r. w sprawie nakazu aresztowania'. W związku z tym, że sprawa ta jest przedmiotem odrębnej analizy w niniejszym zbiorze, w tym tekście nie podlega szczegółowemu omówieniu. Tym niemniej podstawowe tezy wygłoszone przez MTS będą stanowiły punkt wyjścia dla przeglądu późniejszej praktyki.

\section{Wyrok MTS w sprawie nakazu aresztowania}

Przypomnijmy, że sprawa nakazu aresztowania znalazła swój finał przed MTS w następstwie nakazu wydanego przez organy belgijskie przeciwko Abdulaye Yerodii Ndombasi, oskarżonemu o podżeganie do popełnienia zbrodni przeciwko ludzkości oraz zbrodni wojennych w czasie konfliktu w Rwandzie w 1998 r. W czasie wydania nakazu, ścigany sprawował funkcję ministra spraw zagranicznych. Kongo zarzucało Belgii, że poprzez wydanie nakazu dopuściła się naruszenia jego immunitetu pochodzącego z prawa międzynarodowego.

W wyroku MTS uznał, że: „funkcja ministra spraw zagranicznych, ma taki charakter, że osoba ta w czasie pełnienia swojego urzędu korzysta za granicą z pełnego immunitetu od jurysdykcji karnej, jak i nietykalności. Immunitet i nietykalność chronią one taką osobę przeciwko jakiemukolwiek aktowi władczemu innego państwa, który utrudniałby wykonywanie jego obowiązków"10.

Sentencja wyroku MTS był jednoznaczna i nie pozostawiła wątpliwości co do oceny działań Belgii. W uzasadnieniu Trybunał starał się jednak zastrzec, że jego orzeczenie nie powinno być traktowane jako zamknięcie drogi

\footnotetext{
8 Sprawa nakazu aresztowania, pkt 52.

9 ICJ Rep. 2002, s. 3.

${ }^{10}$ Ibidem, pkt. 53 i 54.
} 
do poniesienia odpowiedzialności karnej. Wskazał on cztery ścieżki odpowiedzialności karnej, których istnienie miałoby dowodzić, że immunitet nie oznacza bezkarności ${ }^{11}$ :

- po pierwsze, pochodzący z prawa międzynarodowego immunitet nie obowiązuje przed sądami w państwach obywatelstwa osób ściganych, mogą być oni tam pociągnięci do odpowiedzialności zgodnie z prawem krajowym;

- po drugie, przestają oni być chronieni przez immunitet w przypadku, kiedy państwo, które reprezentują, się go zrzeknie;

- po trzecie, immunitet personalny przestaje obowiązywać w prawie międzynarodowym po ustaniu sprawowania urzędu; byli funkcjonariusze państwowi są wtedy chronieni wyłącznie przez immunitet ratione materiae nieobejmujący tzw. działań prywatnych (commited in private capacity);

- po czwarte, pełniący urząd funkcjonariusze państwowi mogą ponieść międzynarodową odpowiedzialność karną przed określonymi międzynarodowymi trybunałami karnymi, które posiadają jurysdykcję (certain international criminal courts, where they have jurisdiction) ${ }^{12}$.

Powyższy wyrok wyjaśnia szereg istotnych elementów prawa zwyczajowego w zakresie immunitetów najwyższych przedstawicieli państwa, jednakże kilka innych pozostaje nie w pełni skrystalizowanych. Dotyczy to zarówno tych części rozstrzygnięcia, gdzie MTS - jak się wydaje świadomie - zachował otwarte pole do dalszej ewolucji prawa oraz pozostałych, gdzie orzeczenie może pozostawiać niedosyt ze względu na swoją niekompletność. Poniżej omówione zostaną kwestie sporne oraz odpowiedź praktyki, budowanej na ustaleniach MTS, a równocześnie wskazującej na potencjał rozwoju prawa międzynarodowego w tym obszarze.

\section{Zakres podmiotowy immunitetu personalnego}

Krąg osób, którym przysługuje immunitet personalny nie jest określony w sposób ostry. W sprawie nakazu aresztowania MTS nie zdecydował się na jednoznaczne rozstrzygnięcie, stwierdzając, że obejmuje on: „(...) urzędników dy-

${ }^{11}$ Ibidem, pkt 61.

12 W. Czapliński i A. Wyrozumska są zdania, że MTS w ten sposób odwołał się do zasad ogólnych odpowiedzialności oraz zaakcentował fakt, że jurysdykcja musi w każdym przypadku wynikać z prawa międzynarodowego. Nie kwestionując tych założeń, w tym przypadku, naszym zdaniem, Trybunałowi chodziło jedynie o przypomnienie o ograniczeniach jurysdykcji poszczególnych trybunałów międzynarodowych, w szczególności ograniczeniach ratione loci i ratione temporis działających wówczas najbardziej aktywnie MTKJ i MTKR. Zob. W. Czapliński, A. Wyrozumska, Prawo międzynarodowe publiczne. Zagadnienia systemowe, Warszawa 2004, s. 248. 
plomatycznych, konsularnych i niektórych funkcjonariuszy sprawujących najwyższe stanowiska w państwie, takich jak (podkr. - T. O.) głowa państwa, szef rządu i minister spraw zagranicznych"13.

Wyliczenie ma zatem charakter przykładowy i obejmuje trzy kategorie stanowisk objęte na mocy międzynarodowego prawa zwyczajowego immunitetem personalnym: głowę państwa, szefa rządu i ministra spraw zagranicznych. Można zauważyć, że te właśnie osoby są np. uważane za reprezentujące swoje państwo bez potrzeby przedkładania pełnomocnictw dla dokonania wszelkich czynności związanych z zawarciem traktatu ${ }^{14}$.

Objęcie immunitetem personalnym głowy państwa i szefa rządu nie pozostawiało w zasadzie wątpliwości (choć mogą one powstawać w przypadku osoby sprawującej władzę de facto, a także braku uznania państwa) ${ }^{15}$. Znaczącym elementem wyroku MTS w sprawie nakazu aresztowania było natomiast wyraźne potwierdzenie objęcia ochroną przez immunitet personalny również ministra spraw zagranicznych. Uzasadniając swój pogląd, MTS zbadał wnikliwie charakter tego stanowiska i uznał, że nadanie mu pełnej ochrony jest nieodzowne ze względów funkcjonalnych. Wskazał, że minister spraw zagranicznych odpowiada za działania dyplomatyczne, podlega mu personel dyplomatyczny państwa, jego działania mogą wiązać reprezentowane państwo, zaś przy wykonywaniu funkcji jest często zobowiązany do zagranicznych podróży, w związku z czym musi być w stanie swobodnie się poruszać ${ }^{16}$.

Ze względu na przykładowy charakter wyliczenia, zbadać należy możliwość dalszego rozszerzenia zakresu podmiotowego ochrony przez immunitet personalny. Najnowsza praktyka uzupełniła dictum MTS w tym zakresie. Z jednej strony można było obserwować tendencję do uznawania immunitetu funkcjonariuszy pełniących wysokie stanowiska, inne niż tylko wymienione przez MTS, z drugiej jednak ten kierunek orzecznictwa miał swoje ograniczenia.

13 Ibidem, pkt. 51.

${ }^{14}$ Art. 7 ust. 2 Konwencji wiedeńskiej z 1969 r. o prawie traktatów.

${ }^{15}$ Znaczący jest przypadek płk. Kadafiego, który wg francuskiego Sądu Kasacyjnego wykonywał w sposób efektywny funkcje zarezerwowane dla szefów państw, choć formalnie zadania przywódcze spoczywają w Libii w gestii Rewolucyjnej Rady Zarządzającej. Zob. S. Zappala, Do Heads of State in Office Enjoy Immunity from Jurisdiction for International Crimes? The Ghadafi Case Before French Cour de Cassation, EJIL 2001, nr 3, s. 596. Inaczej: sprawa Noriegi: 746 F. Supp. 1056, s. 1519 (S. D. Fla. 1990). W sprawie powiązania immunitetu z uznaniem państwa zob. szerzej: A. Kolodkin, op. cit., s. 5. Z kolei Międzynarodowy Trybunał Karny uznał, że syn płk. Kadafiego Saif Al-Islam sprawował de facto funkcję premiera w Libii (dok. ICC-01/11-4-Red).

16 Sprawa nakazu, pkt 53. Przychylnie na ten temat zob. m.in. S. Wirth, Immunity for Core Crimes? The ICJ's Judgment in the Congo's v. Belgium Case, EJIL 2002, nr 4, s. 889, a także A. Cassese, When May Senior State Officials be Tried for International Crimes? Some Comments on the Congo v. Belgium Case, EJIL 2002, nr 4, s. 855. Z opinią taką nie zgodzili się jednak niektórzy sędziowie MTS, wskazując na sporządzony przez KPM w 1991 r. projekt artykułów o immunitetach jurysdykcyjnych państw i ich własności, zgodnie z którymi immunitety głowy państwa i ministra spraw zagranicznych nie są identyczne. Zob. wspólna opinia sędziów Higgins, Kooijmans i Buerghental, op. cit., pkt 81. Krytycznie także: opinia odrębna sędziego Al-Khasawneh, pkt 2. 
Sąd angielski, powołując się na funkcjonalną interpretację wyroku MTS w sprawie nakazu aresztowania, uznał, że immunitet personalny przysługuje również ministrowi obrony Izraela, Shaulowi Mofazowi. W przeddzień jego wizyty oficjalnej w Anglii wniesiono zawiadomienie o popełnieniu przez niego przestępstwa polegającego na poważnym naruszeniu Konwencji genewskiej z 1949 r. o ochronie osób cywilnych. W orzeczeniu z 12 lutego 2004 r. sąd angielski odmówił wydania nakazu aresztowania ministra, argumentując, iż korzysta on z immunitetu personalnego. Sąd uznał, że „role ministrów obrony i spraw zagranicznych splatają się”, a „sprawy wojskowe odgrywają zasadniczą rolę pomiędzy pewnymi państwami, w szczególności na Bliskim Wschodzie"17. Równocześnie opatrzył to stwierdzenie zastrzeżeniem: „funkcja poszczególnych ministrów różni się w zależności od zakresu ich odpowiedzialności. Jest mało prawdopodobne, aby ministrowie spraw wewnętrznych, pracy, środowiska, kultury czy sportu automatycznie nabyli prawo do ochrony przez immunitet".

Tym samym sąd uznał najwyraźniej, że odmowa ścigania ministra obrony nie powinna być odczytywana jako wsparcie dla nieskrępowanego rozszerzania kręgu funkcjonariuszy chronionych przez immunitet personalny. Z jednej strony, oparł on swoją decyzję na względach funkcjonalnych akcentowanych wcześniej przez MTS w sprawie nakazu aresztowania. $Z$ drugiej jednak, traktował ten wyrok elastycznie, przychylając się najwyraźniej do podejścia ad casum wobec klasyfikacji funkcjonariuszy objętych immunitetem personalnym.

Podobny tok rozumowania, oparty na względach funkcjonalnych, przyjął inny angielski sąd w sprawie Bo Xilai - chińskiego ministra ds. handlu międzynarodowego. W orzeczeniu z 8 listopada 2005 r. uznał, że: ,zgodnie z międzynarodowym prawem zwyczajowym, Bo Xilai korzysta z immunitetu, gdyż nie byłby w stanie wykonywać swoich funkcji bez możliwości swobodnego podróżowania"18.

Powyższe decyzje sądów krajowych mogłyby wskazywać na tendencję do rozszerzania zakresu podmiotowego immunitetu personalnego. W późniejszym orzecznictwie MTS wyraźnie jednak zarysował istniejące ograniczenia. W sprawie pomocy prawnej w sprawach karnych ${ }^{19}$ strony (Dżibuti oraz Francja) zgodziły się co prawda, że immunitet personalny przysługuje również innym wysokim rangą funkcjonariuszom poza ministrami spraw zagranicznych. Jednakże MTS uznał obiter dicta, że Prokurator Krajowy i Szef Służb Bezpieczeństwa Dżibuti z takiego immunitetu nie korzystają ${ }^{20}$. Wydaje się, że nie istnieje również gotowość co do tego, aby rozszerzać immunitet personalny na szefów organizacji międzynarodowych ${ }^{21}$.

17 ICLQ 2004, nr 3, s. 773.

${ }_{18}$ ILR, vol. 128, s. 714. Sąd powołał się jednak także na immunitet wynikający z misji specjalnej.

${ }_{19}$ ICJ Rep. 2008, s. 177.

${ }^{20}$ Ibidem, pkt 194.

21 Zob. D. Akande, Is IMF Managing Director (DSK) Entitled to Immunity from Prosecution?, http://www.ejiltalk.org/is-imf-managing-director-dsk-entitled-to-immunity-from-prosecution (15.11.2011). 
Przykłady z najnowszego orzecznictwa dowodzą zatem, że pole do interpretacji, jakie pozostawił po swoim wyroku MTS, jest wciąż otwarte. Krąg funkcjonariuszy objętych immunitetem personalnym wskazany przez Trybunał miał charakter przykładowy i był uzupełniany przez sądy krajowe. W swoich decyzjach opierały się one zasadniczo na przesłankach funkcjonalnych, tj. służebnej funkcji immunitetu dla nieskrępowanego przebiegu współpracy międzynarodowej. Elastyczne podejście sądów wskazuje jednak, że decyzja w tym przedmiocie może być podejmowana ad casum. Oznacza to, że przyznanie ochrony przez immunitet może zależeć od wewnętrznej organizacji i zadań administracji państwowej (sąd angielski akcentował np. szczególną rolę ministrów obrony „,na Bliskim Wschodzie"). W skrajnej sytuacji można sobie wyobrazić, że funkcjonariusz pełniący takie samo stanowisko w różnych państwach nie będzie objęty identyczną ochroną ze względu na zróżnicowane prerogatywy przyznane w systemie krajowym oraz odmienną rolę w obrocie międzynarodowym. Zaletą takiego podejścia jest margines swobodnej oceny, być może konieczny w tej materii. Równocześnie jednak skazuje ono na element niepewności, który każdorazowo może towarzyszyć decyzjom w przedmiocie immunitetu personalnego funkcjonariuszy innych niż wprost wymienieni w wyroku MTS.

\section{Immunitet personalny a misje specjalne}

W komentarzach po wyroku MTS w sprawie nakazu aresztowania, niektórzy autorzy poddawali w wątpliwość absolutny charakter immunitetu personalnego. Według A. Cassese obowiązuje on jedynie w czasie oficjalnych wizyt. W czasie wizyt prywatnych prawo międzynarodowe nie nakłada takiego zobowiązania. Jego źródłem mogą być wówczas co najwyżej zasady grzeczności międzynarodowej ${ }^{22}$. Inni sugerowali, że o ile głowa państwa korzysta z immunitetu absolutnego, to premierowi ${ }^{23}$ czy ministrowi spraw zagranicznych ${ }^{24}$ winien przysługiwać jedynie przy wizytach oficjalnych. W naszej ocenie, pogląd taki byłby jednak trudny do utrzymania, biorąc pod uwagę dość jednoznaczne stwierdzenia MTS o pełnej ochronie najwyższych funkcjonariuszy państwa, która obowiązuje nawet wówczas, kiedy ścigany funkcjonariusz znajduje się na terytorium obcego państwa (co eliminuje także możliwość wydania międzynarodowego nakazu aresztowania).

${ }^{22}$ A. Cassese, op. cit., s. 117.

${ }_{23}$ Zob. A. Watts, The Legal Position in International Law of Heads of States, Heads of Governments and Foreign Ministers, Receuils des Cours, Haga 1994, s. 102-104.

${ }^{24}$ D. Akande, S. Shah, op. cit., s. 825. 
W toku rozwoju praktyki pojawił się natomiast odwrotny problem, a mianowicie dotyczący zasadności rozszerzenia immunitetu personalnego na inne kategorie niż samych tylko najwyższych funkcjonariuszy. Ochrona taka miałaby przysługiwać w czasie tzw. misji specjalnych.

Immunitet taki został przewidziany w Konwencji z 1969 r. o misjach specjalnych $^{25}$. Zgodnie z art. 29 Konwencji: „osoby przedstawicieli państwa wysyłającego w misji specjalnej oraz członków jej personelu dyplomatycznego są nietykalne”. Art. 31 przewiduje dalej, że ,przedstawiciele państwa wysyłającego w misji specjalnej oraz członkowie jej personelu dyplomatycznego korzystają z immunitetu od jurysdykcji karnej państwa przyjmującego". Immunitet personalny oparty na tej konwencji nie ogranicza się zatem do wąskiej kategorii najwyższych funkcjonariuszy wskazanej przez MTS w wyroku w sprawie nakazu aresztowania. Stronami Konwencji jest dotąd jednak tylko 38 państw. Wskazuje się jednak, że ów przepis konwencyjny mógł przekształcić się w normę prawa zwyczajowego ${ }^{26}$.

W praktyce problem ochrony przez tego rodzaju immunitet powstał w odniesieniu do Rose Kabuye, szefowej Protokołu Prezydenta Rwandy Paula Kagame. W listopadzie 2008 r. została ona zatrzymana na lotnisku we Frankfurcie i wydana do Francji w związku z oskarżeniami o podejmowane w 1994 r. działania terrorystyczne, tj. pomocnictwo w zabójstwie ówczesnego prezydenta Rwandy Juvenala Habyarimana ${ }^{27}$. Organy niemieckie zmuszone były rozstrzygnąć, czy szefowa protokołu prezydenta również jest objęta ochroną przez immunitet personalny. Uznać można by bowiem, że skoro katalog „najwyższych funkcjonariuszy” określony przez MTS jest otwarty, a charakter funkcji pani Kabuye zmusza do częstego podróżowania $\mathrm{w}$ celach dyplomatycznych, to w tym przypadku ze względów funkcjonalnych przysługuje jej immunitet personalny. Alternatywną drogą ochrony byłoby przyznanie immunitetu dyplomatycznego wynikającego z uczestnictwa w misji specjalnej. Postępowanie Niemiec było w tym przypadku niespójne. Ostatecznie odmówiły one uznania immunitetu Rose Kabuye, choć przy okazji jej wcześniejszej wizyty w Niemczech został on jej przyznany właśnie z tytułu uczestnictwa w misji specjalnej. W tym przypadku jednak, wbrew twierdzeniom Rwandy ${ }^{28}$, Niemcy uznały, że jej wizyta miała charakter prywatny. Niejasny status członka misji specjalnej z punktu widzenia ochrony przez immunitet dopro-

${ }^{25}$ Dz. U. z 1985 r., $\mathrm{nr}$ 48, poz. 245.

${ }^{26}$ Zob. np. Yearbook of the International Law Commission, vol. II, 1967, s. 358. W tym kierunku szły również niektóre orzeczenia sądów angielskich i niemieckich. Zob. szczegółowo: D. Akande, S. Shah, op. cit., s. 822.

27 D. Akande, Prosecution of Senior Rwandan Government Official in France: More on Immunity, http://www.ejiltalk.org/prosecution-of-senior-rwandan-government-official-in-france-more -on-immunity/ (15.03.2011).

${ }^{28}$ Government of Rwanda Communiqué on the arrest of Mrs. Rose Kabuye, http://www.minaffet.gov.rw/index2.php?option=com_content\&do_pdf=1\&id=148 (15.03.2011). 
wadził zresztą w późniejszym czasie do odwołania kilku wizyt dyplomatycznych, np. Dana Meridora - izraelskiego ministra ds. wywiadu i energii atomowej, a także Tzipi Livni - byłej minister spraw zagranicznych tego państwa, którzy planowali podróżować do Wielkiej Brytanii ${ }^{29}$. Sprawy te doprowadziły do sformułowania postulatów do uznania w prawie zwyczajowym ochrony przez immunitet personalny przedstawicieli państwa w misji specjalnej. Oznaczałoby to istnienie 2 kategorii osób objętych immunitetem ratione persona ${ }^{30}$ :

1) wąskiej kategorii najwyższych funkcjonariuszy państwowych, stosownie do wyroku MTS w sprawie nakazu aresztowania;

2) przedstawicieli państwa przebywających w misji specjalnej za zgodą państwa przyjmującego.

$\mathrm{W}$ ramach tej drugiej kategorii immunitet obowiązywałby w ograniczonym zakresie temporalnym, tj. w czasie misji specjalnych, a nie zaś wizyt prywatnych. Nadto, w przeciwieństwie do immunitetu personalnego, z którego korzystają najwyżsi funkcjonariusze państwa, nie działałby on erga omnes, lecz wiązał jedynie państwo wysyłające i przyjmujące misję specjalną.

Stwierdzić można, że ewolucja prawa międzynarodowego (zwyczajowego) zmierzająca w kierunku objęcia immunitetem personalnym przedstawicieli państwa w misji specjalnej mogłaby przyczynić się do ustabilizowania obowiązujących na tym polu zasad. W najnowszej doktrynie kierunek ten coraz częściej uzyskuje poparcie ${ }^{31}$. Nieostre określenie przez MTS zakresu podmiotowego immunitetu personalnego wiąże się obecnie $\mathrm{z}$ brakiem pewności prawnej i rodzi ryzyko chaosu w praktyce stosunków międzynarodowych (np. nieskoordynowane odwoływanie wizyt dyplomatycznych). Powszechne przyznanie immunitetu personalnego przedstawicielom państwa w misji specjalnej miałoby zatem doniosłe znaczenie praktyczne, biorąc pod uwagę, że w tym przypadku nie ograniczałby się do tyleż głośnych politycznie, co rzadkich przypadków najwyższych funkcjonariuszy. Immunitet w czasie misji specjalnych wiązałby się zaś z ochroną znacznie szerszej ich grupy, wpływając na codzienną praktykę stosunków międzynarodowych. Z drugiej strony jednak zauważyć trzeba, że przyznanie immunitetu personalnego nieograniczonemu kręgowi przedstawicieli państwa w misji specjalnej oznaczałoby znaczne przesunięcie punktu równowagi, do którego zdawał się dążyć MTS w sprawie nakazu aresztowania. Równowaga ta, jak zaznaczyliśmy, miała polegać na pogodzeniu sprzeczności pomiędzy immunitetem a bezkarnością poprzez zarezerwowanie obszarów ochrony określonych kategorii funkcjonariuszy państwa przy równoczesnym zagwarantowaniu mechanizmów działania międzynarodowej sprawiedliwości karnej.

${ }^{29}$ UK seeks to assure Israel over changing universal jurisdiction, http://www.globalsecurity. org/military/ library/news/2010/11/mil-101104-irna04.html (15.03.2011).

${ }^{30}$ D. Akande, Prosecution... Por. też Ch. Wickremasinghe, Immunities Enjoyed by Officials of States and International Organizations, [w:] M. Evans (red.), International Law, Oxford 2010, s. 395.

${ }^{31}$ D. Akande, S. Shah, op. cit., s. 857 i nast. 
W przypadku powszechnego uznania immunitetu personalnego w misjach specjalnych, balans ten zostałby w decydujący sposób zakłócony. Odtąd szeroka grupa funkcjonariuszy zyskałaby przywilej ochrony niemal tożsamej (za wyjątkiem wizyt prywatnych) z tą, która miała obowiązywać jedynie wobec ich wąskiego kręgu. Jest to wątpliwe o tyle, że niżsi funkcjonariusze oskarżani o najpoważniejsze zbrodnie mogą być stosunkowo łatwo zastąpieni przez innych, na których nie ciążą tego rodzaju zarzuty. Zastanawiać się można zatem, czy immunitet byłby w tym przypadku uzasadniony przez względy funkcjonalne. Wskazuje się także na inne wątpliwości związane z ewentualnością przekształcenia wspomnianych unormowań konwencyjnych w prawo zwyczajowe: stosowania jednolitych standardów w stosunku do wszelkich rodzajów misji, trudności praktycznych wynikających z krótkiego charakteru takiej misji, a także jej niejasnej definicji ${ }^{32}$.

\section{Immunitet personalny a zeznawanie w charakterze świadka}

Inną kwestią niż immunitet od odpowiedzialności karnej jest możliwość zobowiązania osoby objętej immunitetem personalnym przez organy obcego państwa do zeznawania $\mathrm{w}$ charakterze świadka. W doktrynie ograniczano się wcześniej zasadniczo do stwierdzenia, że najwyżsi funkcjonariusze nie mogą być zmuszeni do zeznawania przed obcymi organami niezależnie od powagi zbrodni, gdyż i w tym przypadku na przeszkodzie stoją względy związane z ochroną suwerenności ${ }^{33}$.

Problem ten został rozpoznany przez MTS we wcześniej wspomnianej sprawie wzajemnej pomocy prawnej. W czasie składania przez Prezydenta Dżibuti oficjalnej wizyty we Francji w dniu 17 maja 2005 r., francuski sędzia śledczy przesłał faksem - za pośrednictwem ambasady Dżibuti - wezwanie do złożenia przez niego zeznań następnego dnia, 18 maja, o godz. 9.30. Dwadzieścia minut po przesłaniu faksu Agencja France-Press poinformowała publicznie o tym wezwaniu. Dżibuti złożyło protest przeciwko działaniu sędziego śledczego skierowanego do głowy obcego państwa, zażądało przeprosin i uznania wezwania za nieważne. Wskutek braku stosownej odpowiedzi Francji władze Dżibuti uznały, że doszło do bezprawnego działania naruszającego nie tylko zasady grzeczności międzynarodowej, ale również prawo zwyczajowe oraz konwencyjne odnoszące się do immunitetów ${ }^{34}$.

${ }^{32}$ Ch. Wickremasinghe, op. cit., s. 391.

${ }_{33}$ A. Cassese, op. cit., s. 313.

${ }_{34}$ Dżibuti powołało art. 29 Konwencji wiedeńskiej z 1961 r. o stosunkach dyplomatycznych, co po raz kolejny świadczyć może o zamęcie związanym z myleniem immunitetu dyplomatycznego oraz immunitetu najwyższych funkcjonariuszy. 
Francja twierdziła jednak, że wezwanie Prezydenta do złożenia zeznań miało jedynie charakter zaproszenia, nieobwarowanego żadnymi sankcjami i środkami egzekucji. Zapewniła równocześnie, że w pełni uznaje immunitet głowy państwa oraz przyznała, że miał on pełne prawo odmówić stawienia się. Nie wyklucza to jednak możliwości skierowania stosownego zaproszenia, które samo w sobie nie narusza zasad ochrony przez immunitet.

MTS uznał w wyroku, że elementem decydującym dla rozstrzygnięcia w przedmiocie naruszenia immunitetu jest ustalenie, czy miało miejsce działanie o charakterze władczym (constraining act of authority). Zdaniem MTS, do takiego działania nie doszło. Trybunał podkreślił równocześnie, że zastosowana forma wezwania, tj. przesłanie go faksem z wyznaczeniem bardzo krótkiego terminu, oznaczała złamanie zasady grzeczności międzynarodowej. W konsekwencji MTS ubolewał, iż Francja nie wystosowała przeprosin. Tego rodzaju uchybienie nie stanowi jednak, zdaniem Trybunału, naruszenia immunitetu. Do tego doszłoby dopiero wówczas, jeśli organy francuskie stałyby za przeciekami do Agencji France-Presse. W świetle oficjalnego charakteru wizyty Prezydenta oznaczałoby to naruszenie przez Francję zobowiązań międzynarodowych. MTS nie dysponował jednak żadnymi dowodami na przeciek.

Wyrok ten można ocenić jako kolejną próbę odnalezienia kompromisu pomiędzy słuszną ochroną najwyższych funkcjonariuszy państwa przed interwencją obcych organów, a zapewnieniem choćby cząstkowej możliwości ich zaangażowania w działania wymiaru sprawiedliwości państwa forum. W tym przypadku oznacza to, że zeznawanie w roli świadka nie może przybrać charakteru zobowiązania. Nie wyklucza się jednak innych sposobów wezwania do współpracy, $\mathrm{np}$. w formie zaproszenia.

\section{Immunitet a jurysdykcja}

Rozwój prawa immunitetów zestawić można z równoczesną ewolucją praktyki w zakresie kompetencji jurysdykcyjnych państw. W doktrynie istnieje spór co do charakteru tego powiązania. Zgodnie ze stanowiskiem dualistycznym, jurysdykcja i immunitet stanowią dwie odrębne instytucje prawne, zaś według poglądu monistycznego są to dwa różne aspekty jednej złożonej instytucji. Spór ten nie ma zresztą jedynie charakteru doktrynalnego. Pojawiał się on również pośrednio w orzecznictwie i choć nie został jednoznacznie rozstrzygnięty, to miał znaczenie dla zakresu wyrokowania, a także dla istotnych kwestii proceduralnych ${ }^{35}$.

${ }_{35}$ Zob. np. Sprawa nakazu aresztowania, pkt 46, także: Wspólna opinia sędziów Higgins, Kooijmansa i Buerghentala w tej sprawie, pkt 3. 
Nie rozstrzygając jednoznaczne kwestii powiązań między immunitetem a jurysdykcją, stwierdzić trzeba, że niezależnie od relacji formalno-prawnej, instytucje te bez wątpienia łączy związek funkcjonalny. Problem immunitetu najwyższych funkcjonariuszy państwowych powstaje bowiem, gdy ma dojść do postępowania na forum obcego państwa. Przed obcymi sądami rozstrzygane mogą być zaś tylko te sprawy, w których państwa dysponują jurysdykcją ekstraterytorialną. W interesującym nas obszarze chodzić więc może o zbrodnie międzynarodowe podlegające jurysdykcji znacznie wykraczającej poza zasadę terytorialności, a w pewnych przypadkach sięgające aż jurysdykcji uniwersalnej. Postępowanie nie może być jednak wszczęte w przypadku zaistnienia przesłanki negatywnej, jaką jest ochrona przez immunitet.

Najnowsza praktyka dowodzi, że problemy zakresu eksterytorialnej jurysdykcji i zakresu immunitetu występowały równolegle, towarzysząc ewolucji prawa międzynarodowego. Jej kulminacją była obserwowana w latach 90-tych tendencja do ustanawiania jak najszerszych podstaw jurysdykcji połączona z erozją instytucji immunitetu ${ }^{36}$. W kolejnych latach doszło jednak do korekty tej tendencji. Było to efektem coraz wyraźniejszego ryzyka nadużyć wynikającego z łatwości wszczynania postępowań wobec najwyższych funkcjonariuszy obcych państw. Na płaszczyźnie międzynarodowej wyraźnym sygnałem rewizji liberalnych regulacji w tym zakresie był omówiony wyżej wyrok MTS z 2002 r. w sprawie nakazu aresztowania. Reformy przepisów krajowych, które zostały podjęte w jego następstwie, zmierzały w kierunku stworzenia systemu zabezpieczeń, których głównym celem miało być zapobiegnięcie wykorzystaniu krajowych wymiarów sprawiedliwości do prowadzenia postępowań przeciwko funkcjonariuszom obcych państw. Ograniczenia te przybierały jednakże różnoraki charakter i nie zawsze koncentrowały się bezpośrednio na przepisach odnoszących się do immunitetu.

Problem ten był wyraźnie dostrzegalny w Hiszpanii, która była jednym z państw najbardziej zaangażowanych w praktykę jurysdykcji uniwersalnej ${ }^{37}$, głównie za sprawą słynnego sędziego Baltazara Garzona. Liczne próby wszczynania przed organami hiszpańskimi postępowań przeciwko najwyższym funkcjonariuszom obcych państw zaczęły wreszcie nosić znamiona forum shopping. Doprowadziło to w 2009 r. do przyjęcia ustawy o władzy sądowniczej dwóch poprawek mających ustanowić nowe ramy wykonywania jurysdykcji. W nowelizacji wprowadzono konieczność istnienia łącznika jurysdykcyjnego z Hiszpanią (np. hiszpańskiego obywatelstwa ofiar) jako warunek wszczęcia postępowania. Dodatkowym hamulcem było ustanowienie zasady subsydiarności, zgodnie z którą postępowanie mogło być prowadzone na jej terytorium pod warunkiem, że „efektywne śledztwo” nie zostało wszczęte przez inne państwo lub Międzynarodowy Trybunał Karny ${ }^{38}$.

${ }^{36}$ Zob. szerzej: T. Ostropolski, Zasada jurysdykcji uniwersalnej w prawie międzynarodowym, Warszawa 2008, s. 132 i nast.

37 Zob. ibidem, s. 176 i nast.

${ }^{38}$ Zob. tekst ustawy w: D. Morrison, R. Weiner, Curbing the Manipulation of Universal Jurisdiction, http://www.jcpa.org/text/universal-jurisdiction.pdf (15.03.2011). 
Podobny problem zaistniał w Niemczech, gdzie Kodeks Zbrodni przeciwko Prawu Międzynarodowemu z 2002 r. wprowadzał wyraźne podstawy do wykonywania jurysdykcji uniwersalnej, już wcześniej powoływanej zgodnie z szeroką wykładnią Federalnego Sądu Najwyższego ${ }^{39}$. Jednakże kompetencja ta została obwarowana kilkoma kluczowymi ograniczeniami. Przede wszystkim, zgodnie $\mathrm{z}$ nowym art. $153 \mathrm{f}$ kodeksu postępowania karnego, prokurator może odmówić wszczęcia postępowania w przypadku, gdy osoba ścigana nie przebywa na terytorium Niemiec i jej obecność nie jest przewidywana. Tym samym ustawa dopuszcza wyraźnie oportunizm postępowania in absentia osoby ściganej. Najnowsza praktyka wskazuje jasno, że przepis ten traktowany jest jako pojemna formuła pozwalająca na elastyczne wykorzystywanie w sytuacji, kiedy postępowanie mogło zostać uznane za ryzykowne z politycznego punktu widzenia. Na przykład, prokurator federalny powołał się na ten przepis, odmawiając wszczęcia ścigania m.in. sekretarza obrony USA Donalda Rumsfelda, któremu przypisywano odpowiedzialność za zbrodnie z Abu Ghraib, byłego chińskiego prezydenta Jianga Zemina w sprawie zbrodni przeciwko sekcie Falun Gong czy byłego uzbeckiego ministra spraw wewnętrznych Zokiriona Ałmatowa w sprawie tortur stosowanych przez uzbecką służbę bezpieczeństwa ${ }^{40}$.

Przed podobnym problemem stanęły władze Wielkiej Brytanii w następstwie wyżej wspomnianego odwołania wizyty w tym państwie izraelskich ministrów Dana Merodora i Tzipi Livni, których ostrzeżono, iż możliwe jest wszczęcie przeciwko nim postępowania ${ }^{41}$. W konsekwencji sformułowano projekt ustanowienia wymogu udzielenia zgody na ściganie przez Dyrektora ds. Postępowań Karnych.

Z powyższych przykładów wynika, że wprowadzenie systemu zabezpieczeń przed postępowaniami przeciwko najwyższym funkcjonariuszom obcych państw niekoniecznie odbywa się poprzez ingerencję bezpośrednio w przepisy dotyczące immunitetu. We wskazanych przypadkach zabezpieczenia te polegały bowiem na:

- wprowadzeniu wymogu istnienia określonych łączników w ramach przepisów określających podstawy jurysdykcji,

- ustanowieniu zasady subsydiarności pozwalającej na odmowę wszczęcia postępowania, jeśli może być ono prowadzone w innym państwie dysponującym wyraźniejszymi podstawami jurysdykcyjnymi lub przed międzynarodowym trybunałem karnym oraz

- wyposażeniu organów prokuratorskich w narzędzia pozwalające na dyskrecjonalną odmowę wszczęcia postępowania na podstawie bardziej lub mniej ostrych kryteriów.

${ }^{39}$ Zob. S. Wirth, Germany's New International Crimes Code: Bringing a Case to Court, JICJ 2003, nr 1, s. 151.

${ }^{40}$ Zob. T. Ostropolski, op. cit., s. 170 i nast. oraz cyt. tam literatura.

${ }^{41}$ UK seeks to assure... 
Opisane mechanizmy wyraźnie wskazują na powiązanie między instytucjami jurysdykcji i immunitetu z jednej strony, a ogólnymi przepisami procesowymi z drugiej strony. Choć nie ingerują one bezpośrednio w obszar immunitetów, to zauważyć można, że ich docelowym skutkiem będzie postawienie tamy prowadzeniu postępowań wobec najwyższych funkcjonariuszy. Równocześnie, wykorzystanie tych ograniczeń może być łatwiejsze z punktu widzenia zasady oportunizmu procesowego, gdyż pozwala na wcześniejsze podjęcie decyzji, jej szerszą dyskrecjonalność i tym samym skuteczniejsze zablokowanie ścigania funkcjonariuszy niż sięganie wprost po ochronę wynikającą z immunitetu.

\section{Immunitet najwyższych funkcjonariuszy przed międzynarodowymi trybunałami karnymi - czy bezwzględny wyjątek?}

Powyżej przedstawiona analiza dotyczyła ochrony funkcjonariuszy przed postępowaniami przed sądami obcego państwa. Zasady te nie mogą być natomiast bezpośrednio przeniesione na forum międzynarodowych trybunałów. Okoliczność tę podniósł wprost MTS w wyroku w sprawie nakazu aresztowania, przekonując, iż immunitet nie oznacza bezkarności ${ }^{42}$. Przypomnijmy, że wskazał on postępowanie przed międzynarodowymi trybunałami karnymi, które posiadają jurysdykcję, jako jedną z dróg odpowiedzialności karnej, której nie tamuje immunitet. MTS nie uzasadnił szeroko swojego stanowiska, można jednak uznać, że rozróżnienie to wynika $\mathrm{z}$ odmiennego charakteru postępowania przed sądem krajowym i trybunałem międzynarodowym. Wychodząc z założenia, że ratio dla obowiązywania immunitetów są z jednej strony względy funkcjonalne, a z drugiej ochrona suwerennej równości i godności narodowej, wysunąć można tezę, że te drugie mają mniejsze znaczenie w postępowaniu prowadzonym przed trybunałem międzynarodowym ${ }^{43}$. O ile bowiem postawienie wysokiego funkcjonariusza państwowego przed sądem krajowym obcego państwa może być uważane za naruszenie zasady suwerennej równości, o tyle zarzut ten ma słabsze podstawy w przypadku trybunału międzynarodowego. Ten drugi bowiem posiada z natury ustalone gwarancje rzetelności i nie musi być postrzegany za podmiot konkurencyjny dla państwa-podmiotu, kierującrgo się motywami politycznymi. Zakres ochrony przed międzynarodowymi trybunałami karnymi nie będzie tu przedmiotem szczegółowych dociekań, jednakże

${ }^{42}$ Sprawa nakazu aresztownia, pkt 61.

${ }^{43}$ Zob. S. Wirth, Immunities, Related Problems and Article 98 of the Rome Statute, „Criminal Law Forum" 2001, nr 1, s. 432; M. Płachta, A. Wyrozumska, Problem ratyfikacji Statutu MTK, PiP 2001, z. 5, s. 87 i nast. 
konieczne jest co najmniej sprawdzenie, czy zarysowana przez MTS dychotomia: sąd państwa obcego jako forum objęte przez immunitet versus trybunały międzynarodowe, przed którymi immunitety zostają zniesione, jest zawsze prawdziwa.

Egzemplifikując swoją tezę na temat irrelewantności immunitetów przed trybunałami karnymi czy międzynarodowymi, MTS wyliczył przykładowo Międzynarodowy Trybunał Karny dla b. Jugosławii (MTKJ), Międzynarodowy Trybunał Karny dla Rwandy (MTKR) oraz stały Międzynarodowy Trybunał Karny (MTK). Tym samym do jednego zbioru zaliczył on zarówno trybunały ustanowione przez RB ONZ, korzystającą z uprawnień wynikających z rozdziału VII KNZ ${ }^{44}$, jak i powołany umową międzynarodową MTK. Trudno jednak uznać, że brak tego rozróżnienia był celowy. Wówczas bowiem należałoby wyciągnąć wniosek, że irrelewantność immunitetu dotyczy w takim samym stopniu wszystkich trybunałów międzynarodowych. Musiałoby to m.in. oznaczać bezwzględne zwolnienie z ochrony przez immunitet najwyższych funkcjonariuszy będących obywatelami państw, które nie są stronami umowy statuującej trybunał. Doprowadzić mogłoby to do takiego paradoksu, że funkcjonariusz państwa trzeciego nie byłby chroniony przez immunitet przed jakimkolwiek trybunałem, nawet jeśli byłby on ustanowiony na drodze traktatu przez choćby dwa inne państwa ${ }^{45}$.

Wydaje się więc, że przytoczone wyżej stwierdzenie MTS o irrelewantności immunitetów przed międzynarodowymi trybunałami karnymi powinno zostać opatrzone pewnymi warunkami. Po pierwsze, akty statuujące te trybunały bezpośrednio lub pośrednio wyłączają odpowiedni immunitet (co ma miejsce w statutach większości trybunałów). Po drugie zaś państwo, którego obywatelem jest podejrzany wezwany przed międzynarodowy trybunał, jest związane statuującym go aktem lub też dany trybunał czerpie moc z decyzji RB ONZ (powołującej dany Trybunał na podstawie rozdziału VII KNZ albo powierzającej wykonywanie jurysdykcji ad hoc w danej sprawie).

Przyjąć należy zatem, że immunitety zostają wyłączone przede wszystkim w sytuacji, kiedy trybunał został ustanowiony na podstawie decyzji RB ONZ wynikającej z rozdziału VII KNZ (MTKJ, MTKR, Specjalny Trybunał ds. Libanu). Wówczas prymat zasady irrelewantności pełnionej funkcji publicznej nad immunitetem mającym źródło w ogólnych zasadach międzynarodowego prawa zwyczajowego wynika z art. $103 \mathrm{KNZ}$ nadającego nadrzędny charakter zobowiązaniom wynikającym z Karty ${ }^{46}$.

${ }^{44}$ MTKJ i MTKR zostały ustanowione przez RB w oparciu o rozdział VII KNZ, jako jeden ze środków niewymagających użycia siły, zmierzający do przywrócenia pokoju i bezpieczeństwa międzynarodowego (art. $41 \mathrm{KNZ}$ ).

${ }^{45} \mathrm{Na}$ ten paradoks wskazali amici curiae Specjalnego Trybunału ds. Sierra Leone. Zob. D. Akande, International Law Immunities and the International Criminal Court, AJIL 2004, nr 3.

${ }^{46}$ Nie ma wątpliwości, że przepis ten obejmuje nie tylko zobowiązania wynikające bezpośrednio z KNZ, ale również te powstałe na mocy aktów organów KNZ, które zostały wyposażone w kompetencje do wydawania wiążących decyzji. Zob. R. Bernhardt, Article 103, [w:] B. Simma (red.), The Charter of the United Nations. A Commentary, Oxford 2002, s. 1295. 
W przypadku trybunału powołanego na drodze traktatu trzeba zaś uznać, że zasada irrelewantności pełnionej funkcji publicznej obowiązuje wobec obywateli państw będących jego stronami. Obywatele innych państw korzystają natomiast przed trybunałem $\mathrm{z}$ takiej ochrony, jaka przysługiwałaby im przed obcym sądem krajowym. W przypadku MTK taką wykładnię narzucają zresztą przepisy samego Statutu rzymskiego, który z jednej strony potwierdza naczelną zasadę irrelewantności pełnionej funkcji publicznej (art. 27), z drugiej zaś zakazuje występowania przez Trybunał z wnioskiem o dostarczenie lub pomoc prawną, jeśli mogłoby to prowadzić do naruszenia immunitetu (art. 98) ${ }^{47}$.

Wyjątkiem będzie sytuacja, w której jurysdykcja w danej sprawie została powierzona Trybunałowi ad hoc na mocy decyzji RB działającej na podstawie rozdziału VII KNZ (art. 13 (b) statutu). W przypadku MTK, RB przedstawiła dotąd Trybunałowi sytuację wskazującą na popełnienie zbrodni w Darfurze ${ }^{48}$ oraz w ostatnim czasie w Libii ${ }^{49}$.

W tej pierwszej sytuacji doszło zresztą do sporu, kiedy Zgromadzenie Państw Unii Afrykańskiej stwierdziło, powołując się na art. 98 Statutu rzymskiego, że nie będzie współpracować z MTK w przedmiocie aresztowania i dostarczenia Prezydenta Sudanu Al-Bashira w związku ze sprawą zbrodni w Darfurze ${ }^{50}$. Uznać należy jednak, że, choć Sudan nie jest stroną Statutu rzymskiego, to w następstwie rezolucji RB ONZ immunitet Al-Bashira został w dorozumiany sposób usunięty dla celów postępowania przed MTK, w związku z czym art. 98 statutu w tych okolicznościach się dezaktualizuje ${ }^{51}$.

Sytuacja komplikuje się w przypadku międzynarodowych trybunałów hybrydowych ${ }^{52}$. Problem ten powstał w postępowaniu przed Specjalnym Trybunałem ds. Sierra Leone (STSL) ustanowionym w oparciu o umowę pomiędzy ONZ a rządem Sierra Leone. Punktem wyjścia dla jej zawarcia była przyjęta w $2000 \mathrm{r}$.

${ }^{47}$ Zob. np. P. Gaeta, Official Capacity and Immunities, [w:] A. Cassese, P. Gaeta, J. Jones (red.), Rome Statute of the International Criminal Court. A Commentary, Oxford 2002, s. 996.

${ }^{48}$ Rezolucja RB 1993 (2005).

49 Rezolucja RB 1970 (2011).

${ }^{50}$ Zob. African Union in rift with court, http://news.bbc.co.uk/2/hi/africa/8133925.stm (15.03.2011).

${ }^{51}$ Zob. D. Akande, The Legal Nature of Security Council Referrals to the ICC and its Impact on Al Bashir's Immunities, JICJ 2009, nr 2, s. 333 i nast. Polemicznie: P. Gaeta, Does President Al Bashir Enjoy Immunity from Arrest?, JICJ 2009, nr 2, s. 315 i nast. Nie istnieje jednak jasność nawet w podejściu samego MTK do tej kwestii. W sprawie Kadafiego Prokurator na marginesie wydanego przez siebie nakazu zastanawiał się, czy nie można kwestionować zasadności nakazów zobowiązujących państwa trzecie do dostarczenia osoby (ICC-01/11-4-Red, pkt. 65-67). Zob. też D. Akande, The ICC Prosecutor Requests an Arrest Warrant for Gaddafi: Immunity Issues and Questions about the Start of the Libyan Armed Conflict, http://www.ejiltalk.org/the-icc-prosecutor-requests-an-arrest-warrant-for-gaddafi-immunity-issues-and-questions -about-the-start-of-the-libyan-armed-conflict (15.11.2011).

${ }_{52}$ Zob. ich typologię: C. Romano, A. Nollkaemper, J. Kleffner (red.), Internationalised Criminal Courts, Oxford 2004; M. Płachta, Międzynarodowe trybunaty karne: próba typologii i charakterystyki, PiP 2004, z. 3, s. 14 i nast. 
rezolucja 1315 (2000), w której Rada Bezpieczeństwa stwierdziła istnienie zagrożenia dla międzynarodowego pokoju i bezpieczeństwa $\mathrm{w}$ regionie oraz upoważniła Sekretarza Generalnego do wynegocjowania umowy z Sierra Leone dotyczącej utworzenia „niezależnego specjalnego trybunału”, jako środka podjętego na podstawie art. $41 \mathrm{KNZ}$. Sekretarz Generalny zaproponował ustanowienie trybunału odmiennego niż wcześniej powstałe trybunały ad hoc, „niezakotwiczonego w żadnym istniejącym systemie" ${ }^{53}$. Sam statut Trybunału nie został jednak uchwalony w formie rezolucji $\mathrm{RB}$, lecz dołączono go jako aneks porozumienia zawartego pomiędzy Sierra Leone a ONZ.

Jedno z głównych postępowań przed STSL dotyczyło prezydenta Liberii Charlesa Taylora oskarżonego o popełnienie zbrodni przeciwko ludzkości i poważnych naruszeń Konwencji genewskich, z zamiarem zdobycia dostępu do bogactw mineralnych Sierra Leone. Dnia 23 lipca 2003 r. Taylor złożył wniosek o stwierdzenie nieważności nakazu aresztowania wydanego przez Trybunał, argumentując, iż ze względu na fakt, że w momencie wydania nakazu sprawował funkcję prezydenta Liberii, korzysta z absolutnego immunitetu personalnego. Oskarżony powoływał się przy tym na wyrok MTS w sprawie nakazu aresztowania, w którym potwierdzono nietykalność najwyższych urzędników państwowych i wskazywał dalej, iż wyjątki dotyczące wyłączenia immunitetu przed międzynarodowymi trybunałami karnymi mogą wynikać jedynie z innych norm prawa międzynarodowego, takich jak rozdział VII KNZ ${ }^{54}$. Charakter STSL nie pozwala natomiast, jego zdaniem, na przyrównanie do trybunałów powołanych na mocy rezolucji Rady Bezpieczeństwa ONZ opartych na rozdziale VII KNZ. Stąd zatem, przepis Statutu STSL wyłączający immunitet nie może być skuteczny erga omnes, gdyż moc prawna decyzji wydawanych na jego podstawie odpowiada jedynie mocy prawnej decyzji każdego innego sądu krajowego. Działania STSL wobec Taylora naruszają więc zasadę suwerennej równości ${ }^{55}$.

Argumentacja ta nie została podzielona przez Trybunał. Uznał on, że podstawowa racja obowiązywania immunitetu, jaką jest zasada par in parem non habet imperium, dezaktualizuje się $\mathrm{w}$ razie postępowania na innym forum niż sąd obcego państwa, tj. przed trybunałem międzynarodowym ${ }^{56}$. Skoro więc STSL posiada wszystkie cechy trybunału międzynarodowego, zasada irrelewantności immunitetu również znajdzie w tym przypadku zastosowanie.

Decyzja ta spotkała się ze znaczącą krytyką w doktrynie ${ }^{57}$. Podkreślano, że STSL - jako ustanowiony w drodze umowy, a nie rezolucji RB ONZ

${ }_{53}$ Report of the Secretary General on the Establishment of a Special Court for Sierra Leone, 4.10.2000, UN Doc. S/2000/915.

${ }^{54}$ Prosecutor v. Charles Taylor, op. cit., pkt 6.

${ }_{55}$ Ibidem, pkt 7.

${ }^{56}$ Ibidem, pkt 51.

57 Zob. Z. Deen-Racsmany, Prosecutor v. Taylor. The Statute of STSL and its Implications for the Question of the Immunities of the Incumbent President Before It, s. 299 i nast. oraz S. Nouwen, The STSL and the Immunity of Taylor: the Arrest Warrant Case Continued, LJIL 2005, nr 3, s. 645 i nast.; M. Frulli, The Question of Charles Taylor's Immunity, JICJ 2004, nr 4, s. 1118 i nast.; D. Akande, International Law..., s. 407 i nast. 
- przypomina swoim charakterem raczej MTK niż MTKJ czy MTKR. Implikacją tego muszą być więc odmienne zasady obowiązywania immunitetu. Jego wyraźne zniesienie nie sięga tak daleko jak w przypadku trybunałów czerpiących moc z uprawnień nadanych przez rozdział VII KNZ i dotyczy jedynie stron umowy. Wobec obywateli państw trzecich immunitet funkcjonować winien w zasadzie zgodnie z normami obowiązującymi przed sądami krajowymi tak długo, jak w prawie zwyczajowym nie zostanie uformowana przeciwna zasada mająca zastosowanie do tego typu trybunału. W omówionej wyżej sprawie prezydent Taylor powinien był zatem zostać objęty immunitetem.

Podsumowując tę część rozważań, należy stwierdzić, że działalność międzynarodowych trybunałów karnych stała się kolejnym wyzwaniem dla prawa immunitetów. Rozstrzygnąć należało, czy i w jakim zakresie trybunały są związane immunitetami mającymi źródło w ogólnych zasadach prawa międzynarodowego analogicznie do sądów krajowych. Wyrok MTS w sprawie nakazu aresztowania wprowadził tu pozornie prostą dystynkcję, zgodnie z którą immunitety nie obowiązują przed posiadającymi jurysdykcję międzynarodowymi trybunałami karnymi. Po dokładnej analizie podejście takie wydaje się jednak nazbyt uproszczone. Sam tylko fakt, że postępowanie jest prowadzone przed trybunałem międzynarodowym (niezależnie od jego charakteru) nie powinien sam w sobie prowadzić do wyłączenia immunitetów. Konieczne jest raczej ustalenie ad casum konkretnej przesłanki, która uzasadniałaby wyłączenie ochrony (związanie przez państwo obywatelstwa statutem Trybunału decyzja RB ONZ etc.). Dotychczasowa niejednolita praktyka wskazuje, że kwestia ta wymaga doprecyzowania w orzecznictwie i sformułowania spójnych zasad określających zależność immunitetu od forum, przed którym prowadzone jest postępowanie.

\section{Konkluzje}

Najnowsza praktyka w zakresie immunitetów personalnych najwyższych funkcjonariuszy państwa podlega stałej ewolucji. Po wydaniu przez MTS wyroku w sprawie nakazu aresztowania wydawać się mogło, że doszło do krystalizacji międzynarodowego prawa zwyczajowego w tym zakresie. Szereg kwestii składających się na kształt ochrony przez immunitet personalny pozostało jednak otwartych. Bezwzględnie potwierdzony został immunitet personalny jako absolutna przeszkoda prowadzenia postępowania przed sądem obcego państwa. Trybunał wyjaśnił, że jego zakres podmiotowy obejmuje również osoby pełniące urząd ministra spraw zagranicznych. Nie jest jednak jasne, do jakich jeszcze funkcjonariu- 
szy państwowych, poza głowami państw i szefami rządów, ma on zastosowanie. Późniejsze orzecznictwo potwierdza, że wykracza on poza ten wąski krąg podmiotowy, jednakże nie zakreśla ściśle jego granic.

Kolejny wyrok MTS w sprawie wzajemnej pomocy prawnej potwierdził, że immunitet personalny obejmuje również występowanie w roli świadka w ten sposób, że organ państwa wzywającego nie może stosować aktów władczych, które zobowiązywałyby najwyższych funkcjonariuszy obcego państwa. Równocześnie MTS nie wykluczył przyjęcia przez nich takiej roli procesowej, pod warunkiem zachowania przez państwo prowadzące postępowanie odpowiedniej formy wezwania (zaproszenia).

Jednym z problemów, których rozstrzygnięcie może znacząco wpłynąć na zakres immunitetu personalnego jest ochrona przedstawicieli państwa w misji specjalnej. Pragmatyka stosunków międzynarodowych może powodować narastającą presję na uznanie istnienia tego typu ochrony w międzynarodowym prawie zwyczajowym. Immunitet taki działałby wyłącznie inter partes i nie obejmował wizyt prywatnych. Niemniej jednak, znacznie rozszerzałby zakres podmiotowy ochrony ratione personae poza sam tylko krąg najwyższych funkcjonariuszy. Mogłoby to naruszać postulowaną równowagę pomiędzy stabilnością stosunków międzynarodowych a zasadą międzynarodowej odpowiedzialności karnej.

Relacje pomiędzy immunitetem a jurysdykcją, niezależnie od ich formalnego charakteru (wybór pomiędzy stanowiskiem monistycznym a dualistycznym), stanowią obszar niezwykle intensywnej interakcji, gdzie dopiero całościowa analiza może dać pełny obraz zakresu ochrony najwyższych funkcjonariuszy. Najnowsza praktyka pokazuje, że ochronę taką może w równym lub nawet większym stopniu zapewniać oddziaływanie na przepisy krajowe, dotyczące podstaw jurysdykcji, bądź powiązane z nią regulacje procesowe niż na normy odnoszące się bezpośrednio do immunitetu.

Doprecyzowanie obowiązujących zasad jest konieczne dla ustalenia różnic pomiędzy zakresem ochrony najwyższych funkcjonariuszy przed sądami krajowymi i trybunałami międzynarodowymi. Lakoniczne stwierdzenie MTS dotyczące irrelewantności immunitetów przed posiadającymi jurysdykcję międzynarodowymi trybunałami pozostawiło istotne luki i spotkało się ze słuszną krytyką doktryny, która zwróciła uwagę na konieczność bardziej zniuansowanej oceny. Potrzeba taka uwypukla się na tle multiplikacji trybunałów międzynarodowych (w tym tzw. trybunałów hybrydowych), których charakter jest zróżnicowany i czyni nieadekwatnym przykładanie do nich prostych podziałów.

Podsumowując, stwierdzić należy, że prawo immunitetów nie ma charakteru self-contained, a najnowsza praktyka dowodzi, że dynamika jego rozwoju towarzyszy przeobrażeniom międzynarodowego prawa karnego czy norm dotyczących jurysdykcji. Prognozy o erozji immunitetu okazały się przedwczesne. 
Przełomowym punktem był wyrok MTS w sprawie nakazu aresztowania, w którym Trybunał pośrednio przypomniał, że klasyczne zasady prawa międzynarodowego zakorzenione w porządku westfalskim nie mogą być traktowane jako zdezaktualizowane. Postmodernistyczne tendencje ${ }^{58}$, kwestionujące samą zasadność istnienia immunitetu, jako reliktu przestarzałej doktryny suwerenności państw, która powinna bezwzględnie ustąpić nadrzędnemu celowi, tj. ochronie praw człowieka, mają zaś co najwyżej walor postulatu.

${ }^{58}$ Por. H. Fox, Law of State Immunity, Oxford 2008, s. 2. 